\title{
Dedication to David Dean
}

\author{
Joseph M Ashley ${ }^{1}$, John V Pepper ${ }^{2}$, Kirsten L Rowe ${ }^{1}$, Robert M Schmidt ${ }^{3 *}$ and Steven Stern²
}

\author{
* Correspondence: \\ rschmidt@richmond.edu. \\ ${ }^{3}$ University of Richmond, Richmond, \\ VA, USA \\ Full list of author information is \\ available at the end of the article
}

\begin{abstract}
This special volume is dedicated to David H. Dean who passed away on August 11th, 2013. This dedication describes David's impact on the academic research on disability and, most notably, the vital interaction between research and policy. It discusses his influence in shaping perspectives on evaluating the effectiveness of programs to increase employment. Finally, it describes David as a person and why he was influential as a researcher and college professor.

JEL codes: $\mathrm{H} 51 ;$ i13; J24

Keywords: Vocational rehabilitation; Disability insurance; David Dean
\end{abstract}

We dedicate this special volume to the memory of our colleague and friend, David $\mathrm{H}$. Dean, who passed away on August 11th, 2013. David's research into the economics of disability spanned his entire career of more than thirty years. His interest was kindled as a Rutgers University graduate student by his mentor, Monroe Berkowitz, and continued throughout his career at the University of Richmond. David made a lasting and deep

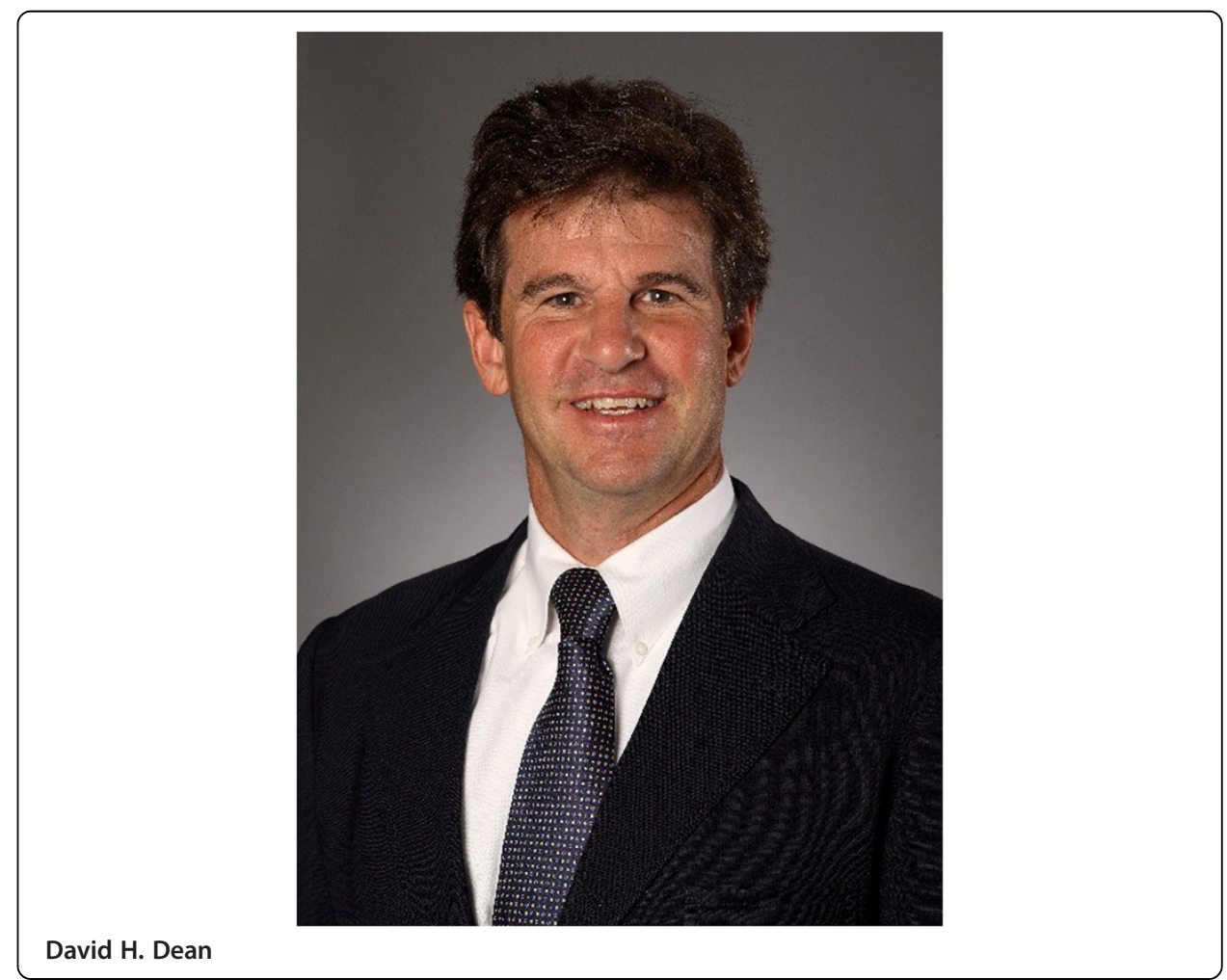

(C) 2014 Ashley; licensee Springer. This is an Open Access article distributed under the terms of the Creative Commons Attribution License (http://creativecommons.org/licenses/by/4.0), which permits unrestricted use, distribution, and reproduction in any medium, provided the original work is properly credited. 
impact on the academic research on disability and, most notably, the vital interaction between research and policy. His work has been enormously influential in shaping perspectives on evaluating the effectiveness of programs to increase employment.

In their remembrances, recent and long-time colleagues provide insight into key reasons why David's work is widely respected. First, David took the time to learn and understand all aspects of programs for persons with disabilities. He developed expertise ranging from the enabling legislation for the various programs, to the institutional workings of federal and state agencies, to the interaction between counselors and customers. David made sure that a research design reflected the nature and values of these programs.

Second, David maintained an unwavering commitment to rigorous research standards. He challenged the traditional approach for evaluating the efficacy of vocational rehabilitation programs. He espoused the use of state-of-the-science statistical approaches to address the likelihood that the "treated" differ from the "untreated" in ways that are unobservable to a researcher. He also lobbied diligently to look at long-term market outcomes rather than simply the difference between reported earnings at closure versus application. And he used his understanding of the vocational rehabilitation program to "crack the black box of VR services" to ensure that the research design reflects VR's individualized nature.

Third, David solicited feedback from all sources and in the process continued to refine his research. David's objective throughout his career was to provide credible and useful information for policymakers and program administrators at the state and federal levels. To that end, David and his co-authors have submitted their research both to academic economics journals as well as rehabilitation journals. He made countless presentations to and solicited feedback from stakeholders at the national and state levels, including agency staff.

Finally, David's personal attributes contributed to his success. His enthusiasm and desire to learn was infectious, traits which endeared him to his students and resulted in numerous teaching awards. He had a strong work ethic, sense of humor, strength of character, and great pride in his work. Most of all, he cared. The field's understanding of the economics of disability will be part of his legacy.

The following two articles from the University of Richmond student newspaper, the Collegian, provide a wonderful perspective on David's dedication to teaching and mentoring.

http://thecollegianur.com/2013/01/29/economics-professors-dedication-unscathed-bycancer/31650/

http://thecollegianur.com/2013/09/02/dean-obit-kerr/35502/

Competing interests

The IZA Journal of Labor Policy is committed to the IZA Guiding Principles of Research Integrity. The authors declare that they have observed these principles.

Responsible editor: Juan F Jimeno

Author details

${ }^{1}$ Virginia Department for Aging and Rehabilitative Services, Richmond, VA, USA. ${ }^{2}$ University of Virginia, Charlottesville, VA, USA. ${ }^{3}$ University of Richmond, Richmond, VA, USA.

Received: 2 June 2014 Accepted: 3 June 2014

Published: 03 Jul 2014

10.1186/2193-9004-3-13

Cite this article as: Ashley et al.: Dedication to David Dean. IZA Journal of Labor Policy 2014, 3:13 